\title{
Anaerobic degradation of acetone by Desulfococcus biacutus spec. nov.
}

\author{
Harald Platen *, Armi Temmes **, and Bernhard Schink \\ Mikrobiologie I, Eberhard-Karls-Universität, Auf der Morgenstelle 28, D-7400 Tübingen, Federal Republic of Germany
}

Received February 20, 1990/Accepted April 19, 1990

\begin{abstract}
From anacrobic digestor sludge of a waste water treatment plant, a gram-negative, strictly anaerobic sulfate-reducing bacterium was isolated with acetone as sole organic substrate. The bacterium was characterized as a new species, Desulfococcus biacutus. The strain grew with acetone with doubling times of $72 \mathrm{~h}$ to $120 \mathrm{~h}$; the growth yield was $12.0( \pm 2.1) \mathrm{g} \cdot[\mathrm{mol} \text { acetone }]^{-1}$. Acetone was oxidized completely, and no isopropanol was formed. In labelling studies with ${ }^{14} \mathrm{CO}_{2}$, cell lipids (including approx. 50\% PHB) of acetone-grown cells became labelled 7 times as high as those of 3-hydroxybutyrate-grown cells. Enzyme studies indicated that acetone was degraded via acetoacetyl-CoA, and that acetone was channeled into the intermediary metabolism after condensation with carbon dioxide to a. $\mathrm{C}_{4}$-compound, possibly free acetoacetate. Acetoacetyl-CoA is cleaved by a thiolase reaction to acetyl-CoA which is completely oxidized through the carbon monoxide dehydrogenase pathway. Strain KMRActS was deposited with the Deutsche Sammlung von Mikroorganismen, Braunschweig, under the number DSM 5651.
\end{abstract}

Key words: Acetone - Acetoacetate - Carboxylation Sulfate reduction

Acetone is degraded by various bacteria under aerobic or anaerobic conditions. It is introduced in to the intermediary metabolism by two different pathways. Most aerobic bacteria use molecular oxygen to form acetol by a monooxygenase reaction (Lukins and Foster 1963; Taylor et al. 1980). Alternatively, an initial condensation of acetone with carbon dioxide to form a $\mathrm{C}_{4}$-compound was suggested for aerobic (Bonnet-Smits et al. 1988) or anaerobic bacteria (Siegel 1950; Platen and Schink 1987, 1989).

Present addresses: * Passavant-Institut für Entwicklung und Umweltanalytik GmbH. D-6209 Aarbergen 7, FRG; ** Metsä-Serla Oy, SF-08800 Kirkniemi, Finland

Offprint requests to: B. Schink
A denitrifying bacterium carboxylates acetone to free acetoacetate in an ATP-dependent reaction (Platen and Schink 1990). From anaerobic enrichment cultures with acetone as substrate and sulfate as electron acceptor, various strains of Desulfococcus multivorans were isolated but not further characterized (Widdel 1988; Widdel personal communication). In this paper we describe enrichment, isolation, and characterization of an acetone-degrading sulfate-reducing bacterium, and report details on its metabolic pathway for acetone degradation.

\section{Materials and methods}

Source of microorganisms

Strain KMRAciS was cnriched from anacrobic sludge of the municipal sewage plant in Marburg, FRG.

\section{Media and growth conditions}

All procedures for cultivation were as previously described (Widdel and Pfennig 1981). The freshwater mineral medium (Schink and Pfennig 1982) for enrichment and further cultivation was carbonatebuffered $(30 \mathrm{mM})$ and sulfide-reduced $(1.0 \mathrm{mM})$, and contained sodium sulfate $(25 \mathrm{mM})$, irace element solution SL 10 , and selenitetungstate solution (1 ml $\cdot 1^{-1}$ of each; Widdel et al. 1983) as well as $0.5 \mathrm{ml} \cdot \mathrm{l}^{-1}$ vitamin solution (tenfold concentrated, after Widdel and Pfennig 1981). Resazurin $\left(0.4 \mathrm{mg} \cdot \mathrm{ml}^{-1}\right)$ was added as redox indicator. The $\mathrm{pH}$ was adjusted to $7.2-7.4$. Acelone was added cither undifuted or as a $1 \mathrm{M}$ solution in sterile water, other carbon soujces were added from 0.5 to $1.0 \mathrm{M}$ stock solutions. Acetoacetate was prepared by the method of Hall (1962).

\section{Microbialogical techniques}

Enrichment cultures were grown in $120 \mathrm{ml}$ serum bottles filled half with medium under a $\mathrm{N}_{2} / \mathrm{CO}_{2}(90 \% / 10 \%)$ gas atmosphere, and sealed with butyl rubber stoppers. Pure cultures were obtained by agar difutions (Pfennig and Trüper 1981) and further cultivated in screw-cap bottles of in serum tubes with butyl rubber stoppers. Growth was measured with a Spcctronic 20 photometer (Milton Roy, Rochester, USA). All cultures were incubated at $28^{\circ} \mathrm{C}$. Gram 
type determination (staining and $\mathrm{KOH}$ assay) and negative staining with Indian ink was carricd out by standard methods (SüBmuth et al. 1987). Microphotographs were taken with an Axiophot microscope (Zeiss, Oberkochen, FRG) with cells immobilized on agar slides (Pfennig and Wagener 1986).

\section{Analysis of cell compounds}

Preparation of DNA and determination of the guanine-pluscytosine content was carried out after Mandel et al. (1970). Lipids and PHB were extracted from freeze-dried cells by shaking for 20 to $24 \mathrm{~h}$ in chloroform $(25 \mathrm{ml}$ chloroform per approx. $100 \mathrm{mg}$ of cells). The extract was filtered through a cellulose filter (type $595^{1 / 2}$, Schleicher and Schüll, FRG), the chloroform evaporated, and the dry residue dissolved in 1 to $4 \mathrm{ml}$ chloroform. Aliquots of this preparation were dried for determination of total lipid content by wet combustion with $\mathrm{K}_{2} \mathrm{Cr}_{2} \mathrm{O}_{7}$ in conc. $\mathrm{H}_{2} \mathrm{SO}_{4}$ (Johnson 1949) with tributyrin as standard. The PHB content of the lipid extract was determined after conversion to crotonic acid with conc. $\mathrm{H}_{2} \mathrm{SO}_{4}$ (Law and Slepecky 1961). Desulfovitidin was detected by the fluorescence test after Postgate (1959), cytochromes were characterized by monitoring absorption spectra of dithionite-reduced against airoxidized cell-free extracts (Uvicon 860 photometer, Kontron, Zürich, Switzerland).

\section{Determination of chemical compounds}

Acetate, isopropanol, and acetone (in the absence of acetoacetate) were determined gaschromatographically (Carlo Erba Vega 6000 with lamc ionisation detector) with a packed column $(2 \mathrm{~m} \times 2 \mathrm{~mm}$ $60 / 80$ Carbopack C/0.3\% Carbowax $20 \mathrm{M} / 0.1 \% \mathrm{H}_{3} \mathrm{PO}_{4}$; Supelco, Bellefonte, USA) by injection of $2 \mu$ of an acidified sample $(100 \mu \mathrm{l}$ sample with $5 \mu 10 \mathrm{M}$ formic acid). Initial oven temperature was $80^{\circ} \mathrm{C}$, and was continuously increased within $2 \mathrm{~min}$ after sample injection to $120^{\circ} \mathrm{C}$. Carrier gas was $\mathrm{N}_{2}\left(40 \mathrm{ml} \cdot \mathrm{min}^{-1}\right)$.

In medium containing acetone and acetoacetate, both substances were determined enzymatically. Cells were removed by centrifugation and the supernatant was diluted with $100 \mathrm{mM}$ potassium phosphate buffer, pH 7.0, to a final concentration of 20 to $200 \mu \mathrm{M} .50 \mu \mathrm{l} 6 \mathrm{mM}$ NADH was added to $950 \mu \mathrm{l}$, the initial absorption was read at $365 \mathrm{~nm}$ wavelength, and the reaction was started either by addition of 0.2 units 3-hydroxybutyrate dehydrogenase (Sigma, Deisenhofen, FRG) or 0.2 units of NAD-dependent isopropanol dehydrogenase (partially purified from the denitrifying bacterial strain BunN; Platen 1989). After 50 min of incubation at $22^{\circ} \mathrm{C}$. the reaction was complete. The system was calibrated with known amounts of acetoacetate or acetone.

Sulfide was determined by the method of Cline (1969). For determination of 3-hydroxybutyrate, $100 \mu \mathrm{l}$ of sample was dried in a test tube, $2 \mathrm{ml}$ of $98 \% \mathrm{H}_{2} \mathrm{SO}_{4}$ was added, and the absorption was determined as described for PHB (Law and Slepecky 1961). Protein was determined by the microbiuret method after Zamenhoff (1957) after removal of sulfide by bubbling with nitrogen gas for a few mimutes.

\section{Labelling experiments}

$\mathrm{Na}_{2}{ }^{14} \mathrm{CO}_{3}$ was obtained from Amersham, Braunschwejg, FRG. Analysis of ${ }^{14} \mathrm{C}$-labelled compounds was carried out as previously described (Platen and Schink 1989).

\section{Preparation of cell suspension and cell-free extracts}

$100 \mathrm{ml}$ cultures in the late exponential growth phase werc centrifuged for $30 \mathrm{~min}$ at $1500 \times \mathrm{g}$ in serum bottles in a GSA rotor with rubber adaptors (Sorvall, Newtown, CT, USA). Cells of 2 to 5 cultures were collected and washed twice under anaerobic conditions with substrate-free medium or with anoxic non-reduced $50 \mathrm{mM}$ MOPS-KOH buffer, $\mathrm{pH}$ 7.2. For cell suspension experiments, cells were suspended in 5 to $30 \mathrm{ml}$ of freshwater medium; cell-free extracts were prepared in MOPS-KOH buffer by French press trcatment (110 MPa) under anoxic conditions. Cell debris was removed by centrifugation in steel tubes under nitrogen al $42000 \times \mathrm{g}$ for $20 \mathrm{~min}$.

\section{Enzyme assays}

Photometric measurements were carried out with a model $100-40$ photometer (Hitachi, Tokyo, Japan) in $1 \mathrm{ml}$-cuvettes of $1 \mathrm{~cm}$ light path with butyl rubber stoppers. All reaction mixtures were prepared anaerobically and contained 10 to $100 \mu \mathrm{g}$ extract protein. E.C. numbers were taken from International Union of Biochemistry (1984).

Propan-2-ol: $N \wedge D^{+}$oxidoreductase (no E.C. number), propan2-ol:NADP ${ }^{+}$oxidoreductase (E.C. 1.1.1.80), 3-hydroxybutanoate: NAD ${ }^{+}$oxidoreductase (E.C. 1.1.1.30), 3-hydroxybutanoate: NADP ${ }^{-}$oxidoreductase (no E.C. number), 3-hydroxyacyl-CoA: NAD ${ }^{+}$oxidoreductase (F.C. 1.1.1.35), and 3-hydroxyacyl-CoA: NADP ${ }^{+}$oxidoreductuse (E.C. 1.1.1.36) werc determincd according to Bergmeyer (1983) in $100 \mathrm{mM}$ MOPS-KOH buffer, $\mathrm{pH} 7.2$, with acetone, Li-acetoacetate, or acetoacetyl CoA, respectively.

Thiolase (E, C. 2.3.1.9) was detected in $100 \mathrm{mM}$ Tris- $\mathrm{HCl}$ buffer (pH 8.2) containing $10 \mathrm{mM} \mathrm{MgCl}, 100 \mu \mathrm{M}$ acetoacetyl-Co.A, and cell-free extract. The reaction was started by addition of $10 \mu \mathrm{l}$ coenzyme $\mathrm{A}(10 \mathrm{mM})$, and decrease of the acetacetyl-CoA-Mg ${ }^{2+}$ complex was detected at $303 \mathrm{~nm}$ wavelength $\left(\varepsilon=14 \mathrm{mM}^{-1} \mathrm{~cm}^{-1}\right.$; Stern 1956). The same assay was used for determination of acetylCoA:acetoacetate CoA transferase (no E.C. number) by roplacing coenzyme $A$ by sodium acetate ( $10 \mu 1$ of $1 \mathrm{M}$ solution).

3-Hydroxybutyryl-CoA dehydratase (4.2.1.55) was detected in $100 \mathrm{mM}$ MOPS-KOH buffer (as above) containing $50 \mu \mathrm{M}$ crotonyl$\mathrm{CoA}$. The reaction was started by addition of cell-free extract, and decrease of extinction at $263 \mathrm{~nm}$ was measured $\left(\varepsilon=6.7 \cdot 10^{3} \mathrm{M}^{-1}\right.$ $\mathrm{cm}^{-1}$; Stern et al. 1956).

Carbon monoxide: methylviologen oxidoreductase (1.2.99.2), formats:methylviologen oxidoreductase (no E.C. number), and pyruvate:methylviologen oxidoreductase (pyruvate synthase; 1.2.7.1) were delected by the method of Diekert and Thauer (1978) in $100 \mathrm{mM}$ potussium phosphate buffer, $\mathrm{pH} 7.0$, containing $2 \mathrm{mM}$ methylviologen and cell-free extract. The reaction mixture for pyruvate:methylviologen oxidoreductase contained also $100 \mu \mathrm{M}$ coenzyme A. Methylviologen wes slightly reduced by traces of sodium ditbionite solution, and the reaction was started by addition of $1 \mathrm{ml}$ carbon monoxide, $10 \mu \mathrm{l} 1 \mathrm{M}$ sodium formate, or $10 \mu \mathrm{l} 1 \mathrm{M}$ sodium pyruvate solution, respcctively $\left(\varepsilon_{578}=9.7 \cdot 10^{3} \mathrm{M}^{-1} \mathrm{~cm}^{-1}\right.$; Daniels et aI. 1977).

Phosphotransacetylase (2.3.1.8.) was detceted after Bergmeyer (1983). Acetate kinase (2.7.2.1) and acetate:CoA ligase (6.2.1.1) were detected in $100 \mathrm{mM}$ MOPS-KOH buffer (pH 7.2) containing cell-free extract, $10 \mathrm{mM} \mathrm{MgCl}, 5 \mathrm{mM}$ ATP, 2.5 mM phosphoenolpyruvate, $0.3 \mathrm{mM}$. NADI, $10 \mathrm{U}$ pyruvate kinasc, and $25 \mathrm{U}$ lactate dehydrogenase; for the detection of acetate: CoA ligase $10 \mathrm{U}$ myokinase was added. The reaction was started by addition of $10 \mu 1$ of $1 \mathrm{M}$ sodium acetate solution, and decrease of absorption at $365 \mathrm{~nm}$ was read (Bergmeyer 1983). Acetoacetate kinase (no F.C. number) and acetoacetate: $C$ A A ligase (6.2.1.16) were determined in the same test system rcplacing acelate by acctoacetate ( $1 \mathrm{M}$ solution of Li-salt).

\section{Chemicals}

All chemicals were of reagent grade quality and obtained from Fluka, Neu Ulm, FRG; Merck, Darmstadt, FRG; Sigma, Deisenhofen, FRG. Gases were obtained from Messer-Griesheim, Darmstadt, FRG. 




Fig. $1 \mathrm{a}$ and $b$. Phase contrast photomicrographs of cells of strain KMRActS. a Condensed cell suspension; $\mathbf{b}$ negative staining with Indian ink. Bar tepresents 10 แ

\section{Results}

\section{Enrichment, isolation, and chatacterization} of strain KMRActS

$60 \mathrm{ml}$ of freshwater medium containing $11.3 \mathrm{mM}$ acetone and $25 \mathrm{mM} \mathrm{Na}_{2} \mathrm{SO}_{4}$ was inoculated with $5 \mathrm{ml}$ anaerobic sludge and incubated at $28^{\circ} \mathrm{C}$. After 68 days, sulfide formation was detected. $5 \mathrm{ml}$ of this culture was transferred to new medium, and turbidity and sulfide formation were observed after 4 weeks. Most bacteria in this culture were of the same shape as the later isolated strain KMRActS. Pure cultures were obtained by two subsequent agar dilutions which were incubated for four to six weeks each.

Strain KMRActS was a gram-negative, lemon-shaped $(1.4 \times 2.3 \mu \mathrm{m})$ bacterium with a big slime capsule (Fig. 1). Cells contained refractile inclusions but did not survive pasteurization (10 min at $80^{\circ} \mathrm{C}$ ). PHB (up to $10 \%$ of cell dry weight), desulfoviridin, and cytochromes were detected (absorption maxima at $553 \mathrm{~nm}$ and $420 \mathrm{~nm}$ wavelength; a $\beta$-band was not detectable); the cytochromes did not precipitate during centrifugation at $150000 \times g$ for $2 \mathrm{~h}$. The guanosine-plus-cytosine content of DNA was $56.5 \pm 0.3 \mathrm{~mol} \%$ as determined by thermal denaturation.
Strain KMRActS had a broad substrate spectrum (details under "species description"); all carbon sources were tested at $10 \mathrm{mM}$ concentration with the exception of benzoate ( $2 \mathrm{mM}$ ). Sulfate and sulfite were reduced to sulfide; thiosulfate, nitrate, fumarate, or sulfur were not used as electron acceptors. Acetone, pyruvate, and 3hydroxybutyrate were not fermented. Growth was completely inhibited by $0.1 \%$ yeast extract.

Optimal growth was obtained at pH-values between 7.2 and 7.8 and 28 to $30^{\circ} \mathrm{C}$ growth temperature; no growth occurred at $37^{\circ} \mathrm{C}$. Strain KMRActS did not grow in saltwater medium, and was inhibited by $>68 \mathrm{mM}$ $\mathrm{NaCl}$ in freshwater medium. Phosphatc inhibited growth completely at $12 \mathrm{mM}$ concentration. $\mathrm{Na}_{2} \mathrm{~S}_{2} \mathrm{O}_{4}$ up to $300 \mu \mathrm{M}$ shortened the lag-phase by 3 to 5 days; higher concentrations inhibited growth.

\section{Stoichiometry of acetone degradation}

Two cultures of 11 volume with $10 \mathrm{mM}$ acetone and $25 \mathrm{mM} \mathrm{Na}_{2} \mathrm{SO}_{4}$ were cultivated for 26 days until the late logarithmic growth phase was reached. Sulfide and residual acetone were determined, and cells were harvested for dry weight determination. In more than five independent experiments, the cell yield was $12.0( \pm 2.1) \mathrm{g}$ per

Table 1. Stoichiometry of acetone degradation by strain KMRActS after growth in 11 cultures with $10 \mathrm{mM}$ acetone and $25 \mathrm{mM}$ sodium sulfate. Details see text

\begin{tabular}{|c|c|c|c|c|}
\hline \multirow[t]{2}{*}{ Acetone consuming reaction } & \multicolumn{2}{|c|}{ Culture no. 1} & \multicolumn{2}{|c|}{ Culture no. 2} \\
\hline & $\begin{array}{l}\text { Measured } \\
\text { parameter }\end{array}$ & $\begin{array}{l}\text { Stoichiometric amount } \\
\text { of acetone used } \\
{[\mathrm{mmol}]}\end{array}$ & $\begin{array}{l}\text { Measured } \\
\text { parameter }\end{array}$ & $\begin{array}{l}\text { Stoichiometric amount } \\
\text { of acetone used } \\
\text { [mmol] }\end{array}$ \\
\hline \multicolumn{5}{|l|}{ Cell material formed ${ }^{a}$} \\
\hline (not including $\mathbf{P H B}$ ) & $71.1 \mathrm{mg}$ & 0.73 & $89.9 \mathrm{mg}$ & 0.93 \\
\hline PHB content of cells ${ }^{\mathbf{b}}$ & $7.3 \mathrm{mg}$ & 0.10 & $1.2 \mathrm{mg}$ & $0.0 ?$ \\
\hline Sulfide formed ${ }^{\circ}$ & $14.6 \mathrm{mmol}$ & 7.30 & $15.3 \mathrm{mmol}$ & 7.65 \\
\hline \multicolumn{5}{|l|}{ Acetone consumption calculated } \\
\hline from formed products & & 8.13 & & 8.59 \\
\hline Acetone consumed (measured) & & 7.43 & & 9.54 \\
\hline Electron recovery & & $109 \%$ & & $90 \%$ \\
\hline $\mathrm{Y}_{\mathrm{s}}\left[\mathrm{g} \cdot(\mathrm{mol} \text { acetone })^{-1}\right]$ & & 11.9 & & 10.6 \\
\hline
\end{tabular}

Amounts of acetone consumed were calculated by the following equations:

" $17 \mathrm{C}_{3} \mathrm{H}_{6} \mathrm{O}+13 \mathrm{CO}_{2}+5 \mathrm{H}_{2} \mathrm{O} \rightarrow 16\left(\mathrm{C}_{4} \mathrm{H}_{7} \mathrm{O}_{3}\right)$

b $9 \mathrm{C}_{3} \mathrm{H}_{5} \mathrm{O}+5 \mathrm{CO}_{2} \rightarrow 8\left(\mathrm{C}_{4} \mathrm{H}_{5} \mathrm{O}_{2}\right)+3 \mathrm{H}_{2} \mathrm{O}$

$\mathrm{C}_{3} \mathrm{H}_{6} \mathrm{O}+2 \mathrm{SO}_{4}^{2-}+4 \mathrm{H}^{+} \rightarrow 3 \mathrm{CO}_{2}+3 \mathrm{H}_{2} \mathrm{O}+2 \mathrm{H}_{2} \mathrm{~S}$ 
Table 2. Growth of strain KMRActS with various substrates and sulfate as electron acceptor. Cells were cultivated in serum tubes sealed with rubber stoppers; the results of one representative growth experiment are shown in each case

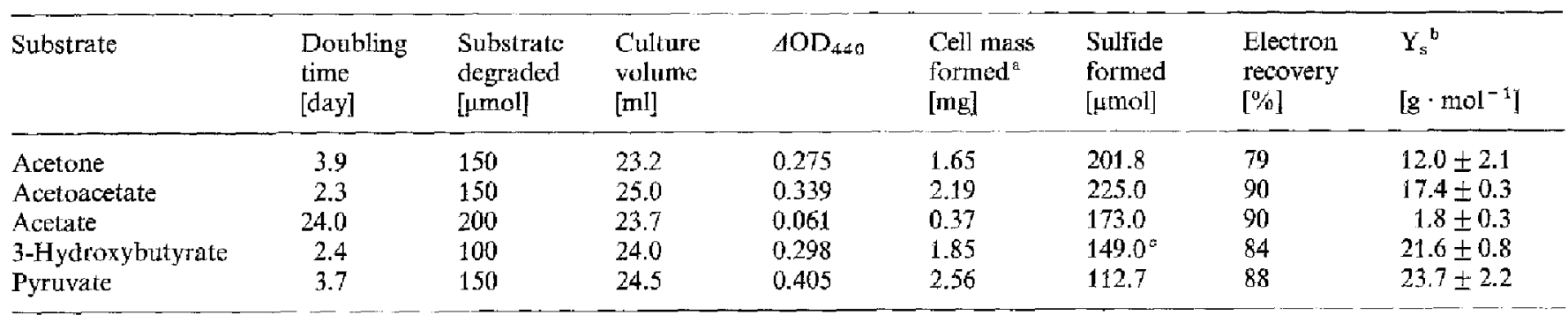

a The $\mathrm{OD}_{440}$ : dry weight calibration value was $258 \mathrm{mg} \cdot \mathrm{OD}^{-1}$; assimilated substrate was calculated after the formula $\mathrm{C}_{4} \mathrm{H}_{7} \mathrm{O}_{3}$ $\left(=\mathrm{C}_{4} \mathrm{H}_{8} \mathrm{O}_{2} \mathrm{~N}\right.$ ) for cell material

b Mean value of 4 to 5 growth experiments with standard deviation. Dissimilated substrate was calculated from total substrate consumption minus assimilated substrate

c The amount of sulfide formed by substrate assimilation was subtracted

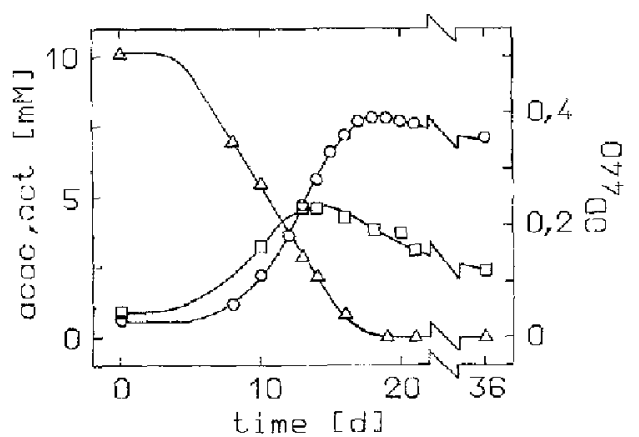

Fig. 2. Growth curve of strain KMRActS with $10 \mathrm{mM}$ acetoactate (acac; $[\Delta]$ ) as substrate and sulfate as electron acceptor. [ $\square]$ Acetone (act), [O] optical density at $440 \mathrm{~nm}$ wavelength

mol acetone with sulfate as electron acceptor (Tables 1 and 2). With sulfite as electron acceptor, the yield was

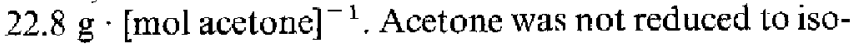
propanol.

\section{Growth with acetate, acetoacetate, and 3-hydroxybutyrate}

Strain KMRActS grew very slowly with acetate; the doubling times were in the range of 19 and 24 days, and growth yields did not exceed $2.1 \mathrm{~g} \cdot \mathrm{mol}^{-1}$ (Table 2 ). With D,L-3-hydroxybutyrate and acetoacetate, growth was faster than with acetone as substrate. Degradation of acetoacetate resulted in a higher growth yield $\left(17.4 \pm 0.3 \mathrm{~g} \cdot \mathrm{mol}^{-1}\right)$ than acetone degradation, however, part of the acetoacetate decarboxylated spontaneously to acetone; the hall-life time of acetoacetate in sterile freshwater medium was 22.3 days at $28^{\circ} \mathrm{C}$ (rate constant of the first order reaction: $1.30 \cdot 10^{-3} \mathrm{~h}^{-1}$ ). A growth curve with acetoacetate is shown in Fig. 2.

\section{Incorporation of ${ }^{14} \mathrm{CO}_{2}$ into cell lipids}

Two replicates of $15 \mathrm{ml}$ dense suspension of acetonegrown cells $\left(O D_{440}=9.8\right)$ in $25 \mathrm{ml}$ serum bottles containing $25 \mathrm{mM} \mathrm{Na} \mathrm{Na}_{2} \mathrm{SO}_{4}$ and $4.51 \cdot 10^{7} \mathrm{dpm} \mathrm{NaH}^{14} \mathrm{CO}_{3}$
Table 3. Incorporation of ${ }^{14} \mathrm{CO}_{2}$ into cell lipids (PHB and membrane lipids) of strain KMRActS after incubation of acetone-grown cells with acetone or 3-hydroxybulyrate (3-OH-BA) as substrate

\begin{tabular}{|c|c|c|}
\hline & \multicolumn{2}{|l|}{ Substrate } \\
\hline & Acetone & 3-OH-BA \\
\hline Substrate consumed [umol] & 101.70 & 83.70 \\
\hline $\begin{array}{l}\text { Rate of substrate consumption } \\
\left.\text { [nmol } \cdot \mathrm{min}^{-1} \cdot \mathrm{ml}^{-1}\right]\end{array}$ & 9.42 & 5.02 \\
\hline Dry cell yiald [mg] & 26.30 & 29.00 \\
\hline Total lipid content (incl. PHB) [mg] & 3.50 & 3.04 \\
\hline PHB [mg] & 1.92 & 2.03 \\
\hline Total ${ }^{14} \mathrm{C}$ in lipids $\left[10^{4} \mathrm{dpm}\right]$ & 29.41 & 3.50 \\
\hline $\begin{array}{l}{ }^{14} \mathrm{CO}_{2} \text { incorporated per substrate con- } \\
\text { sumed }\left[10^{3} \mathrm{dpm} \cdot \mathrm{mol}^{-1}\right]\end{array}$ & 2.89 & 0.41 \\
\hline
\end{tabular}

(specific radioactivity: $9.69 \cdot 10^{4} \mathrm{dpm} \cdot \mu \mathrm{mol}^{-1}$ ) received either $7.7 \mathrm{mM}$ acetone or $8.0 \mathrm{mM}$ D,L-3-hydroxybutyrate. Substrate consumption was linear with time in both cases; acetone was degraded by these acetoneadapted cells twice as fast as 3-hydroxybutyrate. When the substrate was almost consumed, cells were harvested (48000 $\times \mathrm{g}, 30 \mathrm{~min}$ ), washed wice with $25 \mathrm{mM} \mathrm{NH}_{4}{ }^{-}$ acetate solution, and lyophilized. In the extracted lipids of acetone-grown cells, radioactivity was about 7 times as high as in lipids of 3-hydroxybutyrate-grown cells (Table 3).

\section{Enzymes in cell-free extracts of acetone-grown cells}

In cell-free extracts of acetone-grown cells, enzymes of the fatty acid metabolism were detected at high activities, as well as carbon monoxide debydrogenase and formate dehydrogenase (Table 4). These enzymes were also detected in cell-free extracts of acetate- or pyruvate-grown cells with similar specific activities. Neither an enzyme forming free acetoacetate from acetone and $\mathrm{CO}_{2}$ nor an acetoacetate decarboxylating activity could be detected in acetone-grown cells (data not shown). The following enzymes were not detectable in cell-free extracts of acetone-grown cells either: $\mathrm{NAD}^{+}$- and $\mathrm{NADP}^{+}$- depen- 
Table 4. Enzymes detected in cell-free cxtracts of strain KMRAc1S. Cells were grown with acetone as substrate. The data range was obtained in 3 to 4 measurements with various cell-free extracts. The specific acetone consumption rate of exponentially grown cells was 15 to $30 \mathrm{nmol} \cdot[\mathrm{min} \cdot \mathrm{mg} \text { protein }]^{-1}$

$\begin{array}{lll}\text { No. Enzyme } & \begin{array}{l}\text { Specific enzyme } \\ \text { activity }\left(20^{\circ} \mathrm{C}\right) \\ \text { nmol } \cdot[\mathrm{min} \cdot \mathrm{mg}\end{array} \\ \text { protein] }^{-1}\end{array}$

dent propan-2-ol or 3-hydroxybutyrate dehydrogenase, $\mathrm{NADP}^{+}$-dependent 3-hydroxyacyl-CoA dehydrogenase, phosphotransacetylase, acetate- or acetoacetate kinase, acetate- or acetoacetate: $\mathrm{COA}$ ligase, and acetyl-CoA: acetoacetate CoA transferase.

\section{Discussion}

\section{Taxohomy}

Strain KMRActS is an obligately sulfate-reducing bacterium and belongs, thereforc, to section 7 of "Bergey's manual" (Widdel and Pfennig 1984). It is a "complete oxidizer" which oxidizes all substrates to $\mathrm{CO}_{2}$ and $\mathrm{H}_{2} \mathrm{O}$. Morphologically it shares similarities with representatives of the genera Desulfobulbus, Desulfobacter, or Desulfobacterium. However, bacteria of the first two genera do not contain carbon monoxide:methylviologen oxidoreductase (Stams et al. 1984; Schauder et al. 1986), and the guanosine-plus-cytosine content of strain KMRActS does not allow an affiliation with Desulfobacterium either.

Many properties of strain KMRActS are shared with Desulfococcus multivorans (Widdel 1980, 1988; Stieb and Schink 1989). It contains desulfoviridin, at least one $c$ type cytochrome, and a slime capsule, and it has a comparably broad substrate spectrum. Strain KMRActS differs from the type strain by failure of growth with benzoate as substrate; on the other hand, the $D$. multivorans strains 1be1 (Widdel 1980) and Gralbu1 (Stieb and Schink 1989) do not grow with acetone (unpublished). Further differences concern optimum $\mathrm{NaCl}$ concentrations and growth temperature limits. Although the cells are not entirely spherical as typical of a coccus, strain KMRActS sbould be considered due to its physiological characters as a new species of this genus, Desulfococcus biacutus.

\section{Physiology}

Strain KMRActS oxidized acetone completely to $\mathrm{CO}_{2}$. The sevenfold higher incorporation of ${ }^{14} \mathrm{CO}_{2}$ into cell lipids during acetone degradation in comparison with 3hydroxybutyrate degradation indicated that carbon dioxide is needed for acetone degradation as this was found also for other anaerobic acetone degraders (Siegel 1950; Platen and Schink 1987; Bonnet-Smits et al. 1988; Platen and Schink 1989). If acetoacetyl-CoA, which plays a central role in the metabolism of strain KMRActS (see below), is formed after condensation of acetone with carbon dioxide, $\mathrm{PHB}$ and also membrane lipids become radioactively labelled.

Further, acetoacetate was a growth substrate for strain KMRActS; although acetoacetale decarboxylates slowly to acetone and $\mathrm{CO}_{2}$, it is obvious that it was used as a substrate itself because growth yields were higher than with acelone.

A carboxylation reaction seems to be the most plausible mechanism for introduction of acetone into the metabolism. However, all attempts to detect such an enzyme described recently for a denitrifying bacterium (Platen and Schink 1990), failed so far. Enzymes that could activate acetoacetate to its CoA-ester (acetoacetate: $C o A$ ligase, acetoacetate kinase or acetylCoA: acetoacetate CoA transferase) could not be detected either. However, the presence of thiolase and 3hydroxyacyl-CoA dehydrogenase at high activities indicate that acetone degradation occurs via $\mathrm{C}_{4}$-compounds (Fig. 3). The acetyl moiety of acetyl-CoA is oxidized to $\mathrm{CO}_{2}$ via the carbon monoxide dehydrogenase pathway as shown for many other "completely oxidizing" sulfate reducers (Schauder et al. 1986; Spormann and Thauer 1988; Stieb and Schink 1989).

\section{Energetical considerations}

With $70 \mathrm{~kJ}$ needed for irreversible synthesis of $1 \mathrm{~mol}$ ATP under physiological conditions (Thauer et al. 1977), the complete oxidation of acetone by a sulfate reducer could allow a net synthesis of slightly less than 2 ATP:

$$
\begin{aligned}
& \mathrm{H}_{3} \mathrm{C}-\mathrm{CO}-\mathrm{CH}_{3}+2 \mathrm{SO}_{4}^{2-}+4 \mathrm{H}^{+} \\
& \rightarrow 3 \mathrm{CO}_{3(\mathrm{ag})}+2 \mathrm{H}_{2} \mathrm{~S}_{(\mathrm{aq})}+3 \mathrm{H}_{2} \mathrm{O} \\
& \Delta G^{\circ \prime}=-115.3 \mathrm{~kJ} \cdot \mathrm{mol}^{-1}
\end{aligned}
$$

Sulfate-dependent acelate oxidation $\left(\Delta G^{\omega}=-45 \mathrm{~kJ}\right.$. mol ${ }^{-1}$; corresponding to $\left.\leq 2 / 3 \mathrm{ATP} \cdot \mathrm{mol}^{-1}\right)$ by strain KMRActS yielded $1.8( \pm 0.3) \mathrm{g}$ cell matter per mol with very slow growth; other, faster growing strains using the carbon monoxide dchydrogenase pathway, such as Desulfotomaculum acetoxidans, form $4.0 \pm 0.8 \mathrm{~g}$ dry matter per mol (Widdel 1980; Spormann and Thauer 1988). Acetoacetate degradation is much faster and yielded $17.4 \mathrm{~g} \mathrm{cell}$ matter per mol and involves, besides oxidation of two acetate residues, conservation of one ATP equivalent in thiolytic acetoacetyl-CoA cleavage. From these comparisons and the implied growth rates, a $Y_{\text {atp }}$ values for our strain in the range of about 7 to $8 \mathrm{~g}$ per mol ATP can be estimated. Acetone oxidation yielded $12.0 \mathrm{~g}$ dry matter per mol. The free energy change of the total reaction, and comparison with the yield on acetoacetate suggest that acetone carboxylation to a 




cell materict

Fig. 3. Proposed pathway of acetone degradation by the sulfatereducing strain KMRActS. Numbers at the arrows refer to the enzymes listed in Table 4 . The reaction(s) leading from acetone, $\mathrm{CO}_{2}$, and coenzyme A to acetoacetyl-CoA are not yet known acetoacetate residue $[\mathrm{Eq} .(2)]$ is accomplished by a rcaction mechanism consuming less than a full ATP equivalent.

$$
\begin{aligned}
& \mathrm{H}_{3} \mathrm{C}-\mathrm{CO}-\mathrm{CH}_{3}+\mathrm{CO}_{2(\mathrm{aq})} \\
& \rightarrow \mathrm{H}_{3} \mathrm{C}-\mathrm{CO}-\mathrm{CH}_{2}-\mathrm{COO}^{-}+\mathrm{H}^{+} \\
& \mathrm{AG}^{\circ}=+13.6 \mathrm{~kJ} \cdot \mathrm{mol}^{-1}
\end{aligned}
$$

So far, carboxylation reactions driven by only a fraction of an ATP have been observed only in vitro with membrane-bound enzymes energized by a sodium ion gradient (Dimroth and Hilpert 1984; Hilpert et al. 1984). Nitratereducing acetone oxidizers carboxylate acetone to free acetoacetate at the expense of a full ATP (Platen and Schink 1990). It remains an open question how this carboxylation is energized in strain KMRActS; all our attempts to detect any of the known carboxylation reactions have failed so far.

\section{Species description}

Desulfococcus biacutus sp. nov., bi.a.cu'tus, L. adj. biacutus twice pointed, referring to atypical cell shape.

Non-sporulating, shorl rods with pointed ends, $1.4 \times 2.3 \mu \mathrm{m}$ in size, gram-negative, non-motile, big slime capsule, storage material polyhydroxybutyric acid.

Strictly anaerobic chemoorganoheterotroph. Sulfate or sulfite reduced to $\mathrm{H}_{2} \mathrm{~S}$ with the following substrates: acetone, butanone, ethanol, propanol-1, butanol-1, propanol-2 (slow growth), bulanol-2, acetate, propionate, butyrate, valerate, caproate, heptanoate, 2-methylbutyrate, 3-methylbutyrate, crotonate, 3-methylcrotonatc, $D, L-\beta$-bydroxybutyrate, pyruvate, or acetoacetate. No growth with pentanone-2, pentanone-3, $\mathrm{L}(+)$-lactate, fumarate, succinate, malate, citrate, 1,2-propanediol, hydroxyacetone, benzoate, $\mathrm{D}(+)$-glucose, $\mathrm{D}(+)$-galactose, $D(-)$-fructose, and $\mathbf{L}(+)$-arabinose. No fermentation in the absence of inorganic electron acceptors.
Growth optimal in freshwater medium. Growth inhibited by $\mathrm{NaCl}(>68 \mathrm{mM})$, phosphate salts (12 mM), or yeast extract $(0.1 \%)$. Mesophilic; tomperature range $20-30^{\circ} \mathrm{C}$, no growth at $37^{\circ} \mathrm{C} ; \mathrm{pH}$ range $6.8-7.8$, optimum at 7.3 ; cytochrome $b$ and/or $c$; desulfoviridin; carbon monoxide dehydrogenase.

DNA base composition: $56.5 \pm 0.3 \mathrm{~mol} \% \mathrm{G}+\mathrm{C}$ (thermal denaturation). Habitat: anaerobic sludge of a waste water plant. Type strain KMRActS, DSM 5651, deposited with the Deutsche Sammlung von Mikroorganismen (DSM), Braunschweig.

Acknowledgement. The authors are greatly indebted to Dr. F. Widdel, Marburg, for helpiul discussions regarding the taxonomic affiliation of strain KMRActS.

\section{References}

Bergmeyer HU (ed) (1983) Methods of enzymatic analysis, vol I III. Verlag Chemie, Weinheim

Bonnet-Smits EM, Robertson LA, Van Dijken JP, Senior E, Kuenen JG (1988) Carbon dioxide fixation as the initial step in the metabolism of acetone by Thiosphaera pantotropha. J Gen Microbiol 134:2281-2289

Cline JD (1969) Spectrophotometric determination of hydrogen sulfide in natural waters. Limnol Oceanogr 14:454-458

Daniels L, Fuchs G, Thauer RK, Zeikus JG (1977) Carbon monoxide oxidation by methanogenic bacteria. J Bacteriol 132:118126

Diekert GB, Thauer RK (1978) Carbon monoxide oxjdation by Clostridium thermoaceticum and Clostridium thermoaceticum. J Bacteriol 136:597-606

Dimroth P, Hilpert W (1984) Carboxylation of pyruvate and acetyl coenzyme $A$ by reversal of the $\mathrm{Na}^{+}$pumps oxaloacetate decarboxylase and methylmalonyl-CoA decarboxylase. Biochemistry $23: 5360-5371$

Hall LM (1962) Preparation of crystalline lithium acctoacetate. Anal Biochem 3:75-80

Hilpert W, Schink B, Dimroth $P$ (1984) Life by a new decarboxylation-dependent energy conservation mechanism with $\mathrm{Na}^{+}$as coupling ion. EMBO J 3:1665-1670 
International Union of Biochemistry. Nomenclature committee (ed) (1984) Enzyme nomenclature. Academic Press, Orlando, USA

Johnson MJ (1949) A rapid micromethod for estimation of non volatile organic matter. J Biol Chem $181 ; 707-711$

Law JH, Slepecky RA (1961) Assay of poly- $\beta$-hydroxybutyric acid. J Bacteriol 82:33-36

Lukins HB, Foster JW (1963) Melbylketone metabolism in hydrocarbon utilizing mycobacteria. J Bacteriol 85: 1074-1087

Mandel M, Igambi L, Bergendahl J, Dodson MRjr, Scheltgen E (1970) Correlation of melting temperature and cesium chloride buoyant density of bacterial deoxyribonucleic acid. J Bacteriol $101: 330-338$

Pfennig N, Trüper HG (1981) Isolation of members of the families Chromatiaceae and Chlorobiaceae. In: Starr MP. Stolp H, Trüper HG, Balows A, Schlegel HG (ed) The prokaryotes, vol I. Springer, Berlin Heidelberg New York, pp 279-289

Pfennig N, Wagener S (1986) An improved method of preparing wet mounts for photomicrographs of microorganisms. J Microbiol Methods 4:303-306

Platen H (1989) Abbau von $\Lambda$ ceton und höheren aliphatischen Ketonen durch anaerobe Bakterien. Thesis, Universität Tübingen, FRG

Platen H, Schink B (1987) Mcthanogenic degradation of acetone by an enrichment culture. Arch Microbiol 149:136-141

Platen $\mathrm{H}$, Schink B (1989) Anaerobic degradation of acetone and higher ketones via carboxylation by newly isolated denitrifying bacteria. J Gen Microbiol 135:883-891.

Platen H, Schink B (1990) Enzymes involved in anaerobic degradation of acetone by a denitrifying backrium. Biodegradation (submitted)

Postgate JR (1959) A diagnostic reaction of Desulphovibrio desuiphuricans. Nature $183: 481-482$

Schauder R, Eikmanns B, Thaner RK, Widdel F, Fuchs G (1986) Acetale oxidation to $\mathrm{CO}_{2}$ in anaerobic bacteria via a novel pathway not involving reactions of the citric acid cycle. Arch Microbiol 145:162-172

Schink B, Pfennig N (1982) Fermentation of trihydruxybenzenes by Pelobacter acidigalici gen. nov. sp. nov., a strictly anacrobic, non-sporeforming bacterium. Arch Microbiol 133:195 - 201

Siegel JM (1950) The melabolism of acetone by the photosynthetic bacterium Rhodopseudomonas gelatinosa. J Bacteriol 60:595606

Spormann AM, Thauer RK (1988) Anaerobic acetate oxidation to $\mathrm{CO}_{2}$ by Desulfotomaculum acetoxidans. Arch Mictobiol $150: 374-380$
Stams AJM, Kremer DR, Nicolay K, Weenk GII. Hansen TA (1984) Pathway of propionate formation in Desulfobulbus propionicus. Arch Microbiol 139:167-173

Stern JR (1956) Optical properties of acetoacatate-S-coenzyme $\Lambda$ and is metal chelates. I Biol Chem $221: 33-44$

Stern JR, del Campillo A, Raw I (1956) Enzymes of fatty acid metabolism. I. General introduction; crystalline crotonase. I Biol Chem $218: 971-983$

Stieb M, Schink B (1989) Anaerobic degradation of isobutyrate by methanogenic enrichment cultures and by a Desulfococcus multivorans strain. Arch Microbiol 151:126-132

Süßmuth R, Eberspächer J, Haag R, Springer W (1987) Biochemisch-mikrobiologisches Praktikum. Thieme, Stuttgart, FRG

Thauer RK, Jungermann K, Decker K (1977) Energy conservation in chemolrophic anaerobic bacteria. Bacteriol Rev 41:100180

Taylor DG, Trudgill PW, Gripps RE, Harris PR (1980) The microbial metabolism of acetone. J Gen Microbiol 118:159-170

Widdel F (1980) Anaerober Abbau von Fettsäuren und Benzoesäute durch neu isolierte Arten Sulfate-reduzierender Bakterien. Thesis, University Göttingen, FRG

Widdel F (1988) Microbiology and ecology of sulfate- and sulfurreducing bacteria. In: Zehnder AJB (ed) Biology of anaerobjc microorganisms. Wiley, New York, pp $469-585$

Widdel F, Pfennig N (1981) Studies on dissmilatory sulfate-reducing bacteria that decompose fatty acids. I. Isolation of a new sulfatereducer enriched with acetate from saline environments. Description of Desulfobacter postgatei gen. nov. sp. now. Arch Microbiol 129:395-400

Widdel F, Pfennig N (1984) Dissimilatory sulfate- or sulfur-reducing bacteria. In: Krieg NR, Holl JG (eds) Bergey's manual of systematic bateriology, vol I. Williams \& Wilkins, Baltimore, USA, pp 663-679

Widdel F, Kohring GW, Mayer F (1983) Studies on dissinilatory sulfate-reducing bacteria that decompose fatty acids. III. Characterization of the filamentous gliding Desulfonema limicala gen. nov. sp. nov., and Desulfonema magnum sp. nov. Arch Microbiol 134:286-294

Zamenhoff S (1957) Preparation and assay of desoxyribonucleic acid from animal tissue. In: Colowick SP, Kaplan NO (eds) Methods in enzymology, vol III. Academic Press, New York, pp $696-704$ 